\section{Nauplius}

The Journal of The

Brazilian Crustacean Society

e-ISSN 2358-2936

www.scielo.br/nau www.crustacea.org.br
This article is part of the special series offered by the Brazilian Crustacean Society

in honor to Ludwig Buckup

his dedication and contributions to the development of Carcinology

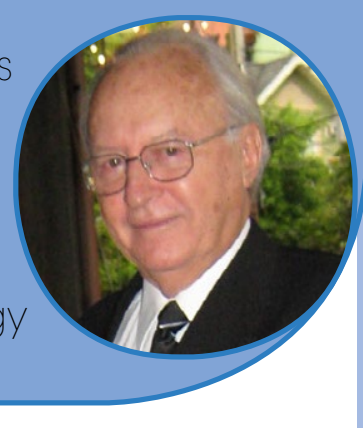

Original Article

\title{
New endemic species of freshwater crayfish Parastacus Huxley, 1879 (Crustacea: Decapoda: Parastacidae) from the Atlantic forest in southern Brazil
}

\author{
Augusto Frederico Huber ${ }^{1}$ (D) orcid.org/0000-0002-4590-3049 \\ Felipe Bezerra Ribeiro ${ }^{1,2}$ (D) orcid. org/0000-0002-8623-1576 \\ Paula Beatriz Araujo ${ }^{1,2}$ (D) orcid.org/0000-0002-7587-3936
${ }^{1}$ Departamento de Zoologia (Laboratório de Carcinologia), Instituto de Biociências, Universidade Federal do Rio Grande do Sul. Porto Alegre, Rio Grande do Sul, Brazil.
${ }^{2}$ Programa de Pós-graduação em Biologia Animal, Departamento de Zoologia (Laboratório de Carcinologia), Instituto de Biociências, Universidade Federal do Rio Grande do Sul. Porto Alegre, Rio Grande do Sul, Brazil.

ZOOBANK: http://zoobank.org/urn:lsid:zoobank.org:pub:B8B0DE0E-E0B1-4C46A6C0-F501EAF35B05

\section{Abstract}

Two new species of Parastacus Huxley, 1879 are described from the Atlantic Forest in southern Brazil: Parastacus buckupi sp. nov. from a highland stream in the hydrographic basin Maquiné river, Maquiné, state of Rio Grande do Sul; and Parastacus pilicarpus sp. nov. from a first order stream in the hydrographic basin Araranguá River, Morro Grande, state of Santa Catarina. Parastacus

CORRESPONDING AUTHOR Augusto Frederico Huber gutofh@yahoo.com.br

SUBMITTED 16 October 2017 ACCEPTED 20 April 2018 PUBLISHED 25 June 2018

\section{Guest Editors}

Alessandra Angélica de Pádua Bueno and Sandro Santos

DOI 10.1590/2358-2936e2018015

\section{(cc) BY}

All content of the journal, except where identified, is licensed under a Creative Commons attribution-type BY.

Nauplius, 26: e2018015 buckupi sp. nov. is distinguishable from all other Parastacus species via its large and globose chelipeds, by the presence of tufts of long and simple setae in the cutting edge of cheliped fingers, which are more abundant proximally and by possessing a telson with an acute distal margin. Parastacus pilicarpus sp. nov. is diagnosed mainly by the distal portion of the carpus which possess tufts of long, simple setae, and by having an epistome whose anteromedian lobe is heptagonal and as long as it is wide. Finally, P. pilicarpus antennal scales lateral margin terminates in a very strong terminal spine and mandibles incisive lobe has nine teeth, with the first tooth from the anterior margin 
being the largest. The conservation status based on the sub-criterion B1 of IUCN Red List allowed us to classify these species as "ENDANGERED” and "DATA DEFICIENT", respectively.

\section{KEY WORDS}

Astacidea, Neotropical region, taxonomy, limnetic ecosystems, freshwater decapods.

\section{INTRODUCTION}

Brazil is known for its biodiversity and unique biomes such as the Atlantic Forest, which is considered one of the most biodiverse areas in the world (Mittermeier et al., 2004). The forest is distributed along the Brazilian coast, from the state of Piauí to the state of Rio Grande do Sul. Approximately $88.27 \%$ of its original extension has been lost and only 16,377,472 ha remain (Ribeiro et al., 2009). In its southernmost region, the rivers and lakes of the Atlantic Forest harbor great aquatic biodiversity, including decapod crustaceans such as freshwater anomuran crabs of the genus Aegla Leach, 1820, true crabs of the family Trichodactylidae, prawns of the families Atyidae and Palaemonidae, and freshwater crayfish including members of the genus Parastacus Huxley, 1879 (Melo, 2003).

The genus Parastacus is composed of eleven species that occur in the southern portion of South America: Argentina, Brazil, Chile and Uruguay (Buckup and Rossi, 1980; 1993; Ribeiro et al., 2016; 2017). The crayfishes of this genus have a disjoint distribution, with two species occurring on the plains of the southern Andean region in Chile: Parastacus nicoleti (Philippi, 1882) and Parastacus pugnax (Poeppig, 1835) (Philippi, 1882; Poeppig, 1835; Rudolph, 2010; Ribeiro and Araujo, 2017); and nine species distributed in Argentina, southern Brazil and Uruguay: Parastacus brasiliensis (von Martens, 1869), Parastacus caeruleodactylus Ribeiro \& Araujo in Ribeiro et al. (2016), Parastacus defossus Faxon, 1898, Parastacus fluviatilis Ribeiro \& Buckup in Ribeiro et al. (2016), Parastacus laevigatus Buckup \& Rossi, 1980, Parastacus pilimanus (von Martens, 1869), Parastacus saffordi Faxon, 1898, Parastacus tuerkayi Ribeiro, Huber \& Araujo in Ribeiro et al. (2017) and Parastacus varicosus Faxon, 1898 (Buckup and Rossi 1980; Ribeiro et al., 2016; 2017).

In Brazil, the species of Parastacus are recorded only in the states of Rio Grande do Sul (RS) and Santa Catarina (SC) (Buckup and Rossi, 1980). Parastacus laevigatus and $P$. tuerkayi are endemic to SC, while P. brasiliensis,
P. caeruleodactylus and P. fluviatilis are endemic to RS (Buckup, 2003; Ribeiro et al., 2016; 2017).

The aim of this contribution is to describe two new species of Parastacus collected from first order streams in RS and SC, Brazil. The habitat characterization and the conservation status based on the IUCN Red List criteria are provided for both species.

\section{Material and Methods}

\section{Morphological analysis}

The type material was deposited in the Museu de Zoologia of the Universidade de São Paulo (MZUSP), São Paulo, Brazil, and in the Carcinological Collection of the Departamento de Zoologia, Instituto de Biociências, Universidade Federal do Rio do Grande do Sul (UFRGS), Porto Alegre, Brazil. The comparative material is deposited in UFRGS. The drawings were made with the aid of a stereomicroscope fitted with a camara lucida. All measurements were performed with vernier caliper with $0.1 \mathrm{~mm}$ accuracy and a millimetric ocular on a stereomicroscope. Shape and size of the S2 pleura were defined according to Ribeiro et al. (2016). Sex was identified based on the morphology of the gonopores according to Rudolph (1997). Morphological descriptions are based on Riek (1971), Buckup and Rossi (1980), Hobbs (1987), Morgan (1997), Holdich (2002) and Ribeiro et al. (2016; 2017). Branchial count follows Huxley (1879). The taxonomic classification follows Crandall and De Grave (2017).

\section{Comparative material examined}

Brazil, Rio Grande do Sul: Parastacus brasiliensis one female, Morro da Agronomia, Porto Alegre, 26/ XI/1975 (UFRGS 278); one male and one female, Vila Jardim, Porto Alegre, 25/V/1963, coll. N. Klevaco (UFRGS 282); one female, Parque Natural Morro do Osso, Porto Alegre ( $\left.30^{\circ} 07^{\prime} 19^{\prime \prime S} 51^{\circ} 14^{\prime} 01^{\prime \prime} \mathrm{W}\right), 2010$, coll. K.M. Gomes \& A. Kessler (UFRGS 5338); one 
female, Morro Santana, Porto Alegre, 26/IX/2012, col. K.M. Gomes (UFRGS 5757); one female, Praça da Vila Jardim Renascença, Porto Alegre (3009'77.20”S 51¹9'17.40”W), 10/VII/2013, coll. K.M. Gomes, F.B. Ribeiro \& G.C. Dalló (UFRGS 5861); two males, Viamão, Parque Saint'Hillaire (UFRGS 279). Parastacus fluviatilis - one female, Divisa river, São José dos Ausentes, 3/X/2002, coll. G. Bond-Buckup (UFRGS 2059); one male, Divisa river, Silveira/São José dos Ausentes (28³8’43.91”S 4956’27.67”W), 15/V/2014, coll. F.B. Ribeiro \& K.M. Gomes (UFRGS 6436); one male, Morro Monte Negro, São José dos Ausentes, 03/X/2002, coll. G. Bond-Buckup (UFRGS 2293). Parastacus pilimanus - one female, São Sebastião do Caí, IV/1997, col. M. Verdade (UFRGS 2191); one male and one female, Estrada do Ligeiro, Maquiné, 02/ VIII/1999, coll. F.G. Becker, T. Finker \& P. Colombo (UFRGS 6233).

\section{Conservation analysis}

The extinction risk of the new species was defined according to the B1 sub-criterion, sub-items "a" and " $b$ " of the International Union for Conservation of Nature - IUCN (IUCN 2012). This sub-criterion takes into consideration the estimated Extent of Occurrence (EOO) which was calculated in Arcview 9.3 program (ESRI, 2009). The definition of the hydrographic basins follows the Otto Bacias shape method (level 4) (ANA, 2006).

Abbreviations

SLP = Thoracic Sternite Lateral Processes

S1 = Pleonal Somite 1

S2 = Pleonal Somite 2

$\mathrm{TL}=$ Total Length

$\mathrm{CL}=$ Carapace Length

$\mathrm{CW}=$ Carapace Width

$\mathrm{CD}=$ Carapace Depth

$\mathrm{CeL}=$ Cephalon Length

$\mathrm{RL}=$ Rostral Length

RW = Rostral Width

$\mathrm{RCL}=$ Rostral Carina Length

CMW $=$ Cornea Maximum Width

OW $=$ Orbital Width

POCL $=$ Post Orbital Carina Length

FW $=$ Frontal Width
ASL $=$ Antennal Scale Length

ASW $=$ Antennal Scale Width

AreL $=$ Areola Length

AreW $=$ Areola Width

RPrT/LPrT $=$ Right/Left Propodus Thickness

RPrL/LPrL = Right/Left Propodus Length

RPrW/LPrW = Right/Left Propodus Width

$\mathrm{RDL} / \mathrm{LDL}=$ Right/Left Dactylus Length

RML/LML = Right/Left Merus Length

$\mathrm{PL}=$ Pleon Length

PW $=$ Pleon Width

TeL $=$ Telson Length

TeW $=$ Telson Width

The definition of each measurement can be found in Ribeiro et al. (2016), with the exception of PL and PW following the definition of pleon by Schram (2013).

\section{Other abbreviations}

sni - sex not identified

$\mathrm{w} / \mathrm{n}$ - without number

Gon - Female Gonopore Maximum Width

F - Female

M - Male

\section{Systematics}

Infraorder Astacidea Latreille, 1802

Superfamily Parastacoidea Huxley, 1879

Genus Parastacus Huxley, 1879

Parastacus buckupi sp. nov.

(Figs. 1-3, 8)

Parastacus brasiliensis._ Vilella et al., 2004: 22.

Type material. Holotype: male, Brazil, Rio Grande do Sul, Maquiné, Arroio Carvão (UTM 574562/6731725), 23/V/2001, coll. F.S. Vilella (MZUSP 36515). Paratypes: 1 - Brazil, Rio Grande do Sul: one male, Maquiné, Arroio Carvão, 25/X/2001, coll. F.S. Vilella (UFRGS 3581); 2 - one male, Maquiné, Arroio Carvão, 17/VIII/2001, coll. F.S. Vilella (UFRGS 3893); 3 - one female, Maquiné, Arroio Carvão, 
17/VIII/2001, coll. F.S. Vilella (UFRGS 3894); 4 - one female, Maquiné, Arroio Carvão, 25/X/2001, coll. F.S. Vilella (UFRGS 3895); 5 - one male, Maquiné, Arroio Carvão, 25/X/2001, coll. F.S. Vilella (UFRGS 3896).

Etymology. Named in honor of the Emeritus Professor Ludwig Buckup from Universidade Federal do Rio Grande do Sul, Porto Alegre, Rio Grande do Sul, Brazil. He was one of the pioneers of carcinological studies in Brazil, dedicating several years of his life to the study of decapod crustaceans, especially conducting research on the biology and taxonomy of freshwater crayfish.

Diagnosis. Narrow cephalon front with a short triangular rostrum. Rostral apex inverted U-shaped with an upward blunt spine. Suborbital angle $90^{\circ}$. Postorbital carinae weakly prominent. Cervical groove weakly $\mathrm{V}$-shaped. Areola narrow, $2.1 \mathrm{x}$ as long as wide. Telson with acute distal margin. Mandible with caudal molar process unicuspidate with one cephalodistal cusp, incisive lobe with ten teeth. S2 pleurae low and long with shallow groove parallel to margin. Chelipeds large and globose with the cutting edge of fingers covered by tufts of long and simple setae more abundant in the proximal portion.

Description of the holotype. Rostrum: triangular, longer than wide (RW $89 \%$ of RL), short (10\% of $\mathrm{CL})$, reaching proximal portion of the second article of the antennular peduncle (Fig. 1A-C). Dorsum straight, apex inverted U-shaped, ending in an upward blunt spine (Fig. 1B, C). Few plumose setae on lateral margins. Rostral carinae almost straight, prominent and narrow, extending back to carapace, surpassing rostral basis (Fig. 1B, C); sides convergent and basis slightly divergent (Fig. 1B).

Cephalon: Carapace lacking spines or tubercles. CeL 63.41\% of CL. Eyes small (CMW 65\% of OW); suborbital angle $90^{\circ}$ and unarmed (Fig. 1C). Front narrow (FW36\% of $\mathrm{CW}$ ). Postorbital carinae longer than rostral carinae (RCL $71 \%$ of POCL) and weakly prominent. Lateral cephalic edge with sparse setation (Fig. 1A-C).

Thorax: carapace laterally compressed, deep and wide (CD $42 \%$ of CL; CW $45 \%$ of CL). Cervical groove weakly $\mathrm{V}$-shaped. Branchiocardiac grooves inconspicuous (Fig. 1A). Areola narrow, 2.1x as long as wide ( $31 \%$ of $\mathrm{CL}$ ) (Fig. 1A).
Pleon: lacking spines or tubercles, short and wide (PL 65\% of CL; PW 83.4\% of CW), smooth, sparsely covered with small setae on pleural margins (Fig. 1A). Pleural somites with rounded posterior margins. S1 pleurae with a large distal lobe not overlapped by S2 pleurae. S2 pleurae low and long with shallow groove parallel to margin (Fig. 1D-F).

Tailfan: telson weakly calcified in the distal margin, subrectangular, longer than wide (TeW $90 \%$ of TeL), with small sharp spines on lateral margins; acute distal margin with abundant long plumose setae and short simple setae; dorsal surface with tufts of short setae and inconspicuous dorsomedian longitudinal groove (Fig. 1G). Uropod protopod bilobed, with rounded and unarmed margins; proximal lobe largest (Fig. 1G); exopod lateral margin bears a small and sharp spine, mid-dorsal carina few prominent, ending in a sharp spine; transverse suture (diaeresis) straight, with four dorsolateral spines (outer) and four dorsolateral spines (inner) on right exopod and six dorsolateral spines (outer) and five dorsolateral spine (inner) on the left exopod; endopod, mid-dorsal carina few prominent, ending in a very sharp spine; lateral margin with one sharp spine at level of diaeresis (Fig. 1G).

Epistome: anterolateral section with a blunt conical projection. Posterolateral section smooth and with deep lateral grooves converging to the basis of the anteromedian lobe, and small median circular concavity. Anteromedian lobe pentagonal, as long as wide, apex acute and straight with serrate setae, reaching median part of antepenultimate article of antennal peduncle; dorsal surface straight, and basis with a shallow groove (Fig. 2A).

Thoracic sternites: SLP4 smallest and close to each other, median keel present and not inflated; SLP5 small and close to each other, median keel present and not inflated; SLP6 larger than SLP4 and SLP5 and with a slightly concave surface, median keel inflated; SLP7 largest and with surface slightly concave, median keel inflated, bullar lobes absent; SLP8 small and slightly concave, median keel absent, vertical arms of paired sternopleural bridges close to each other, bullar lobes separated and clearly visible (Fig. 2B, C).

Antennule: internal ventral border of basal article with one small sharp spine (Fig. 2A).

Antenna: when extended back reaching up to the posterior margin of the carapace. Antennal scale 


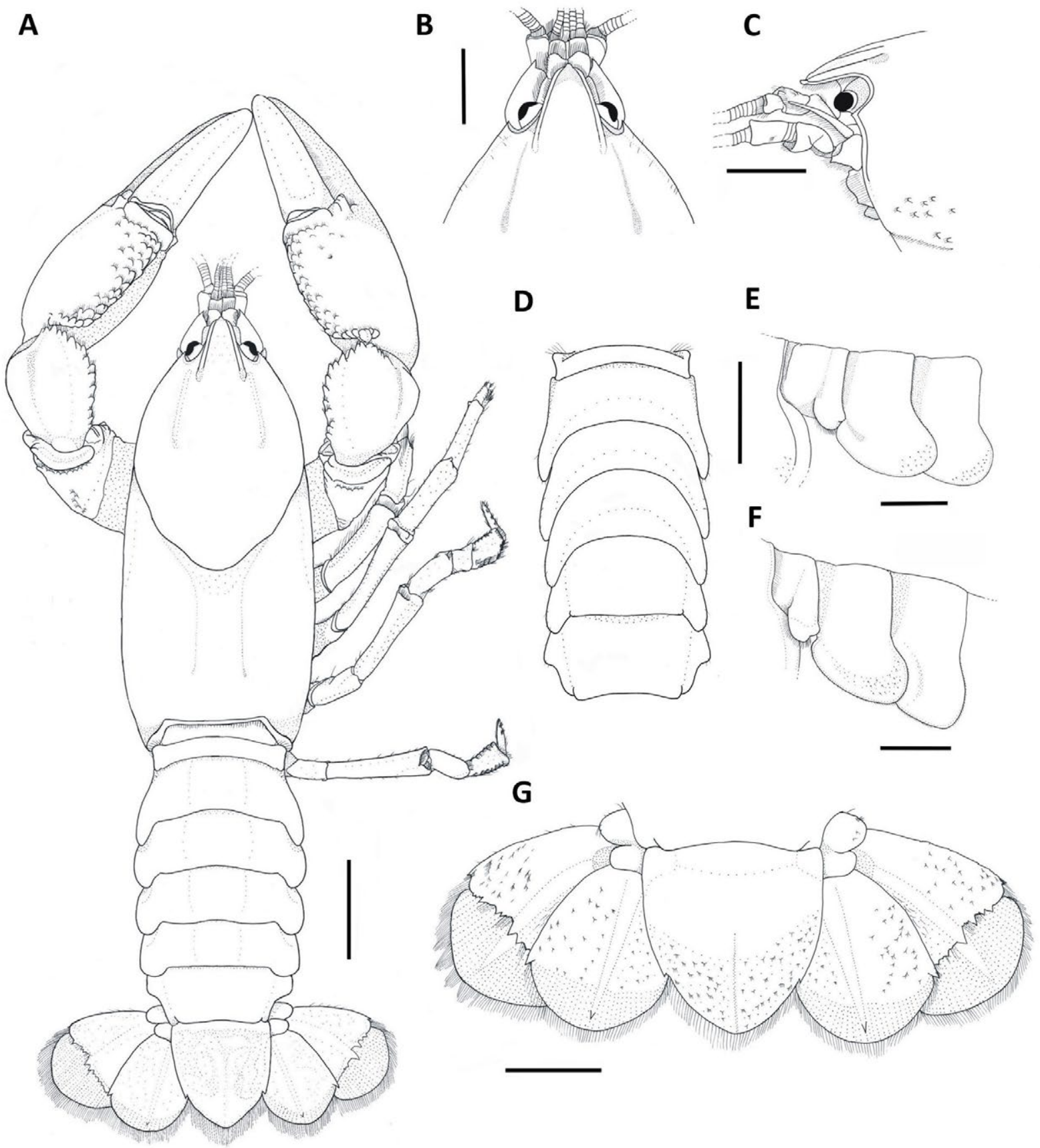

Figure 1. Parastacus buckupi sp. nov. A, habitus dorsal view (holotype); B, cephalon dorsal view (holotype); C, cephalon lateral view (holotype); D, female pleon (paratype 4); E, male first to third pleonal pleura (holotype); F, female first to third pleonal pleura (paratype 4); G, tailfan dorsal view (holotype). Scale bars: A - $1 \mathrm{~cm}$; B-D, G - 5 mm; E, F-3.33mm.

widest distally at midlength, reaching midlength of third antennal article, ASW 42.7\% of ASL (Fig. 2A, D), lateral margin curved with strong spine and distal margin straight. Coxa with prominent carina above nephropore and a blunt spine laterally displaced. Basis unarmed (Fig. 2A).

Mandible: cephalic molar process molariform, caudal molar process unicuspidate with one cephalodistal cusp.
Incisive lobe with ten teeth. The fourth tooth from the anterior margin is the largest (Fig. 2E).

Third maxilliped: ischium, ventral surface partially covered by tufts of long and simple setae (Fig. 2F); dorsal surface glabrous (Fig. 2G). Crista dentata bearing 27 and 30 teeth in right and left ischium respectively. Merus ventral surface partially covered by tufts of long and simples setae. Exopod longer than ischium, 
A

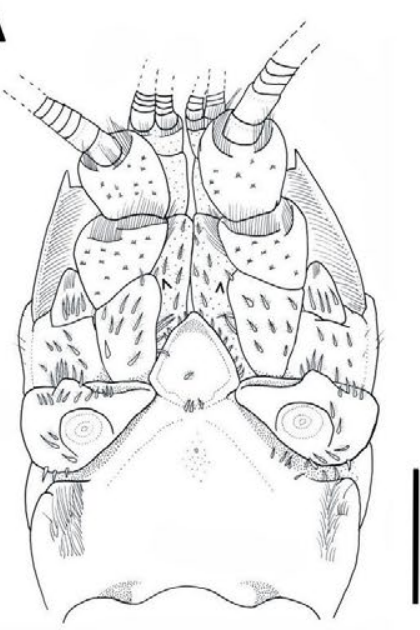

E

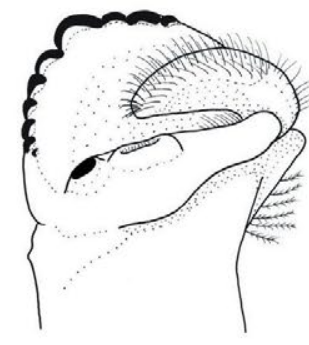

B

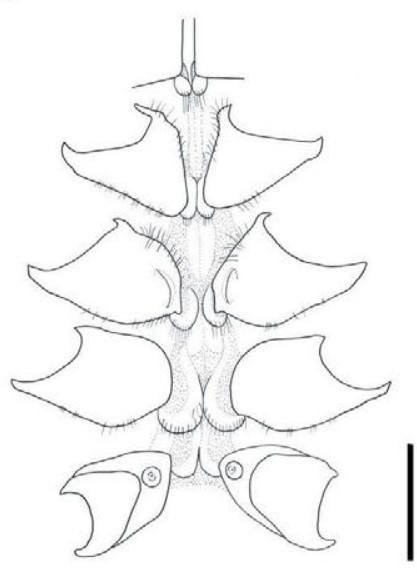

$\mathbf{F}$

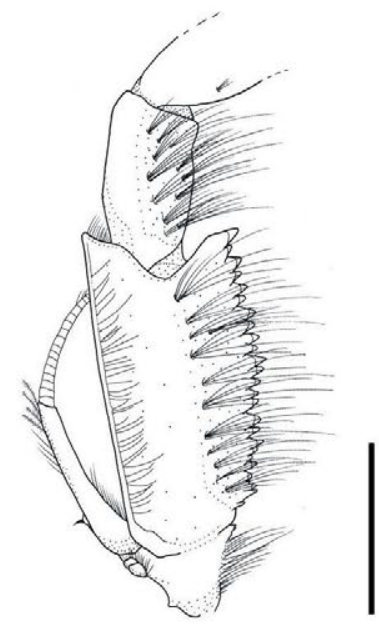

C

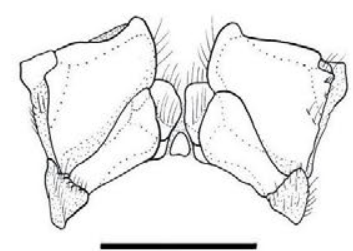

D

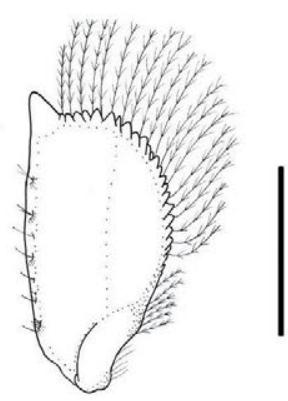

G

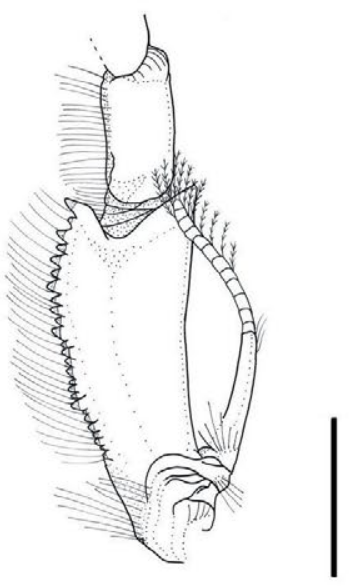

H
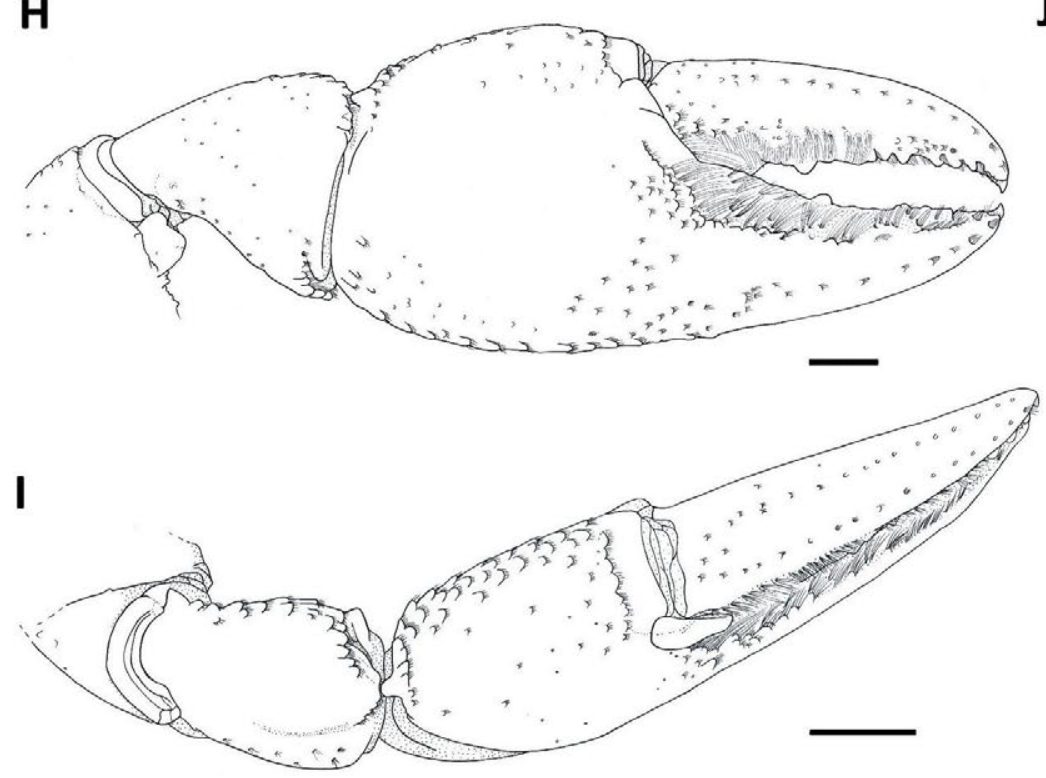

J

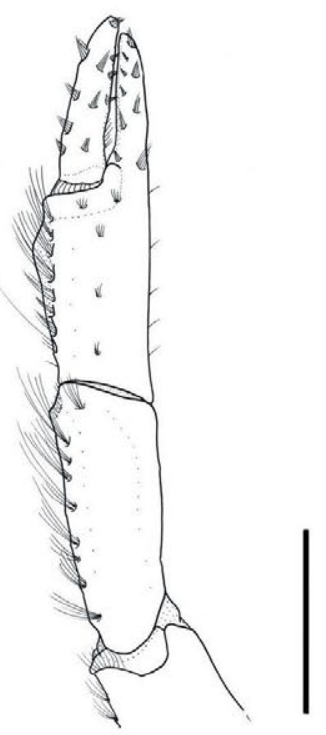

Figure 2. Parastacus buckupi sp. nov. A, epistome (holotype); B, thoracic sternites and gonopores (holotype); C, thoracomere 8, caudal view (holotype); D, antennal scale lateral view (paratype 4); E, mandible (paratype 4); F, third maxilliped ventral view (paratype 4); $\mathrm{G}$, third maxilliped dorsal view (paratype 4); H, first pereiopod lateral view (holotype); I, first pereipod dorsal view (holotype); J, second pereiopod lateral view (holotype). Scale bars: A - $3.3 \mathrm{~mm} ; \mathrm{B}, \mathrm{H}-\mathrm{J}-5 \mathrm{~mm}$; C, D - $1.6 \mathrm{~mm}$; F, G - $2.50 \mathrm{~mm}$; E - $2.00 \mathrm{~mm}$. 
with flagellum reaching proximal margin of merus (Fig. 2F, G).

First pair of pereiopods (chelipeds): large and subequal, globose (RPrT 29.4\% of RPrL; LPrT 29.3\% of LPrL) (Figs. 1A; 2H, I). Ischium ventral surface with 17 tubercles. Merus: right merus (RML) 50.5\% of propodus length (RPrL); left merus (LML) 53.2\% of propodus length (LPrL); ventral surface with two longitudinal series of tubercles: inner series with 16 tubercles, outer 17 and mesial 26, arranged irregularly on right merus; inner series bearing 13 tubercles, outer 16 and mesial 21, arranged irregularly on left merus; dorsal and midventral spine absent. Carpus with dorsomedial surface divided longitudinally by shallow groove (Fig. 1A; 2I). Internal dorsolateral margin with row of tubercles, distally increasing in size; inner surface with up to nine small mesial tubercles; carpal spine absent (Fig. 2I). Propodus width (RPrW and LPrW) $49.3 \%$ of length in right cheliped and $49.5 \%$ in left cheliped; dorsal surface of palm with squamose tubercles irregularly distributed (Fig. 2H, I); inner margin without tubercles; ventral surface bearing two rows of squamose tubercles, reaching the beginning of the fixed finger (Fig. 2H). Dactylus: moving subvertically, right dactylus (RDL) $57.6 \%$ of propodus length (RPrL), left dactylus (LDL) $57.5 \%$ of left propodus (LPrL); dorsal surface without tubercles (Fig. 2I). Cutting edge of fingers covered by tufts of long and simple setae more abundant in the proximal portion (Fig. $2 \mathrm{H}$ ). Fixed finger and dactylus both bearing seven teeth, the third teeth is the largest. (Fig. 2H, I).

Second pair of pereiopods: ventral and dorsal surface of carpus, propodus and dactylus with sparse covering of simple long setae (Fig. 2J).

Gonopores: Presence of both genital apertures on coxae of third and fifth pairs of pereiopods. Female gonopores semi-ellipsoidal (maximum diameter 1.46 $\mathrm{mm}$ ) with a well-calcified membrane. Male gonopores rounded, opening onto apical end of a small, fixed, calcified and truncated phallic papilla, close to inner border of ventral surface of coxae of fifth pair of pereiopods. Male cuticle partition present (Fig. 2B).

Branchial count: $20+$ epr $+\mathrm{r}$. Branchial arrangement follows the same described by Huxley (1879) and Hobbs (1991) with the epipod of the first maxilliped with rudimentary podobranchial filaments.
Measurements. Holotype male, CL $39.11 \mathrm{~mm}$ and TL $74.76 \mathrm{~mm}$. In type series, CL ranging from 12.28 to $39.11 \mathrm{~mm}(22.42 \pm 9.44 \mathrm{~mm})$. FW/CW: $0.37 \pm$ 0.02 (min: 0.35; $\max : 0.41$ ). RL/RW: $1.2 \pm 0.1$ (min: 1.08; max: 1.33). MCW/OW: $0.72 \pm 0.1$ (min: 0.55; max: 0.82). Postorbital carina longer than rostral carina in all specimens. CW/PW: $1.17 \pm 0.04$ (min: 1.12; $\max : 1.25$ ). AreW/RW: $1.08 \pm 0.26$ (min: 0.73; $\max$ : 1.46) (Tab. 1).

Color of living specimens. Rostrum dark brown. Antennal flagellum light brown. Cephalothorax anterior and lateral regions dark brown to reddish brown. Chelipeds brown with dark brown fingers. Pereiopod pairs 2-5 light brown to dark brown. Dorsal pleon and tailfan light brown to reddish brown (Fig. 3C).

Remarks. Parastacus buckupi sp. nov. is morphologically similar to $P$. brasiliensis in having a wide pleon, large chelipeds, rostral apex inverted U-shaped with an upward blunt spine and a pentagonal anteromedian lobe of epistome. Parastacus buckupi sp. nov. is also similar to P. fluviatilis and P. pilimanus in having the cutting edge of fingers covered by tufts of long and simple setae (Fig. 7). Parastacus buckupi sp. nov. differs from all other Parastacus species by the large and globose chelipeds with tufts of plumose setae in the cutting edge of fingers, which are more abundant in the proximal portion (Fig. 7A) and telson subrectangular with acute distal margin (Fig. 1A, G). It was observed that the distal margin of the telson is rounded in smaller specimens (Paratype 1-5; Tab. 1). All specimens are intersexed. In males paratypes, the female gonopores are semi-ellipsoidal (average maximum diameter $1.76 \mathrm{~mm}$ ) covered by a calcified membrane. The male gonopores are similar in all type material.

Habitat and Ecology. Carvão stream is included in the Serra Geral Biological Reserve (Vilella et al., 2004), with headwaters located about $800 \mathrm{~m}$ above sea level (a.s.l.; Fig. 3A, B). This stream is nearly $3.5 \mathrm{~km}$ of length with a catchment area of approximately $6 \mathrm{~km}^{2}$ and the margins are surrounded by riparian vegetation including Araucaria angustifolia (Bertol.) Kuntze, 1898 and grasslands (Araucaria Forest province) (IBGE, 1990; Vilella et al., 2004; Sydow et al., 2008; Morrone, 
Table 1. Measurements (mm) of the type series of Parastacus buckupi sp. nov. For abbreviations see Material and Methods section.

\begin{tabular}{|c|c|c|c|c|c|c|}
\hline & $\begin{array}{c}\text { Holotype } \\
\text { (MZUSP 36515) }\end{array}$ & $\begin{array}{c}\text { Paratype 1 } \\
\text { (UFRGS 3581) }\end{array}$ & $\begin{array}{c}\text { Paratype 2 } \\
\text { (UFRGS 3893) }\end{array}$ & $\begin{array}{c}\text { Paratype } 3 \\
\text { (UFRGS 3894) }\end{array}$ & $\begin{array}{c}\text { Paratype } 4 \\
\text { (UFRGS \#3895) }\end{array}$ & $\begin{array}{c}\text { Paratype } 5 \\
\text { (UFRGS 3896) }\end{array}$ \\
\hline Sex & M & M & M & F & F & M \\
\hline $\mathrm{TL}$ & 74.76 & 49.03 & 30.77 & 31.05 & 47.24 & 46.42 \\
\hline CL & 39.11 & 23.76 & 14.5 & 12.28 & 22.62 & 22.27 \\
\hline $\mathrm{CW}$ & 17.59 & 9.6 & 6.28 & 6.5 & 8.96 & 9.59 \\
\hline $\mathrm{CD}$ & 16.38 & 13.48 & 7.39 & 8.41 & 12.23 & 12.42 \\
\hline CSL & 24.8 & 16.35 & 10.29 & 10.58 & 15.29 & 14.36 \\
\hline $\mathrm{RL}$ & 4.39 & 3.3 & 2.23 & 2.48 & 2.53 & 2.86 \\
\hline RW & 3.91 & 2.48 & 1.84 & 1.87 & 2.34 & 2.43 \\
\hline CMW & 1.41 & 1.24 & 0.79 & 0.9 & 1.23 & 1.11 \\
\hline OW & 2.17 & 1.62 & 1.43 & 1.12 & 1.5 & 1.49 \\
\hline FW & 6.34 & 3.66 & 2.35 & 2.69 & 3.49 & 3.45 \\
\hline RCL & 6.08 & 4.16 & 2.65 & 2.31 & 3.65 & 3.65 \\
\hline POCL & 8.58 & 5.18 & 3.67 & 3.25 & 4.86 & 4.68 \\
\hline ASL & 4.42 & 3.26 & 1.8 & 1.81 & 2.68 & 2.43 \\
\hline ASW & 1.89 & 1.54 & 1.03 & 0.99 & 1.41 & 1.39 \\
\hline $\mathrm{AuL}$ & 12.06 & 6.03 & 3.66 & 4.07 & 5.93 & 6.11 \\
\hline $\mathrm{AuW}$ & 5.73 & 2.31 & 1.36 & 2.16 & 2.2 & 3.12 \\
\hline PW & 14.68 & 8.43 & 4.99 & 5.76 & 7.69 & 8.23 \\
\hline PL & 25.4 & 20.4 & 13.45 & 11.54 & 17.88 & 16.22 \\
\hline RPrT & 9.39 & 4.47 & 3.12 & 1.46 & 5.06 & 3.74 \\
\hline RPrL & 31.92 & 18.18 & 10.01 & 5.8 & 16.94 & 13.65 \\
\hline RPrW & 15.75 & 7.99 & 4.78 & 1.78 & 8.7 & 6.78 \\
\hline RML & 16.12 & 10.05 & 5.32 & 4.52 & 9.52 & 8.95 \\
\hline $\mathrm{RDL}$ & 18.38 & 10.37 & 5.68 & 3.45 & 9.64 & 7.98 \\
\hline LPrT & 9.34 & 6.08 & 2.93 & 3.43 & 4.69 & 5.87 \\
\hline LPrL & 31.89 & 21.19 & 10.28 & 11.52 & 16.11 & 18.44 \\
\hline LPrW & 15.77 & 9.59 & 4.71 & 5.39 & 8.22 & 8.88 \\
\hline LML & 16.96 & 11.17 & 5.74 & 6.89 & 9.83 & 9.67 \\
\hline LDL & 18.34 & 11.71 & 6.04 & 6.09 & 8.66 & 9.86 \\
\hline $\mathrm{TeL}$ & 10.8 & 6.98 & 3.98 & 4.61 & 6.46 & 6.47 \\
\hline $\mathrm{TeW}$ & 9.73 & 6 & 3.76 & 3.57 & 5.56 & 5.46 \\
\hline Gon & 1.76 & 1.13 & 0.37 & 0.58 & 1.08 & 1.11 \\
\hline
\end{tabular}

2014). The substrate of the creek is basaltic with arenite in the lower portions (Vilella et al., 2004) (Fig. 3A, B). Data concerning burrow morphology and burrowing behavior are not available since they were not recorded when the specimens were collected. However, it is possible that the new species shows some level of burrowing activity especially considering that the burrowing behavior is probably found in all species of Parastacus (Buckup and Rossi, 1980).

Distribution. Parastacus buckupi sp. nov. is so far recorded in Carvão stream in the municipality of Maquiné, state of Rio Grande do Sul, southern Brazil (Fig. 8).

Conservation status. The EOO was estimated at approximately $301.885 \mathrm{~km}^{2}$ (Fig. 8), indicating that this species can be included in the Endangered - EN category, in which the EOO is less than $5,000 \mathrm{~km}^{2}$ (IUCN, 2012). The species is categorized as EN under the subitem "a": for an EOO, which is severely fragmented; and subitem " $b$ " (iii): continuing decline in quality of habitat. Both subitems are compatible with the threats existing in the species occurrence area: a small fragment of a stream with approximately $6 \mathrm{~km}^{2}$ of catchment area (Vilella et. al., 2004). The region of Maquiné basin is impacted mainly through the substitution of natural vegetation by agriculture (Becker et al., 2004). Conservation in the Maquiné basin is of fundamental importance since the region constitutes the southern limit of dense Ombrophylous Forest (Atlantic Forest) and all associated animals and plants (Bencke and Kindel, 1999; Becker et al., 2004). We suggest therefore that the conservation status of this species be classified as ENDANGERED $\mathrm{B} 1 \mathrm{ab}(\mathrm{iii})$. 

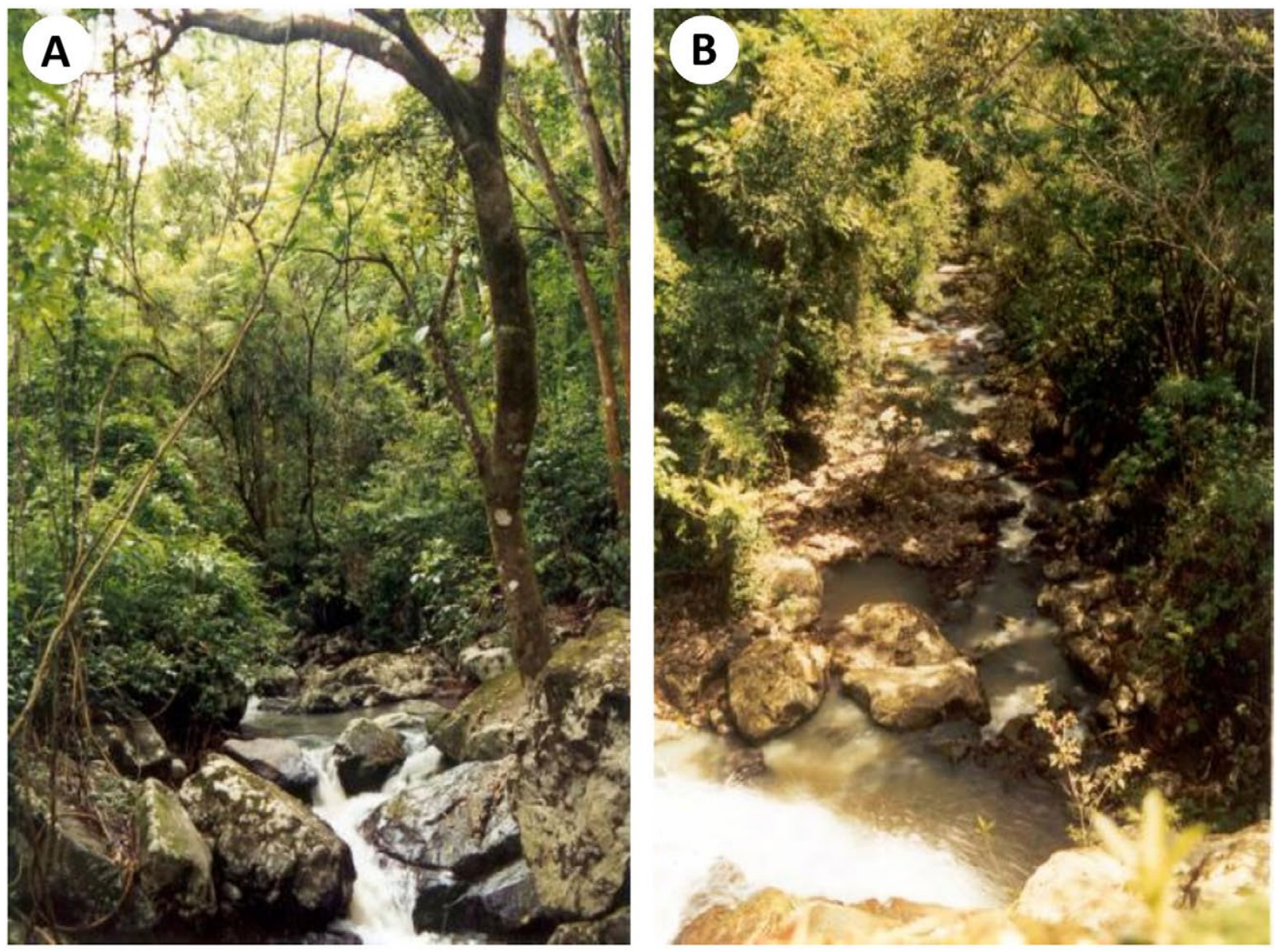

C

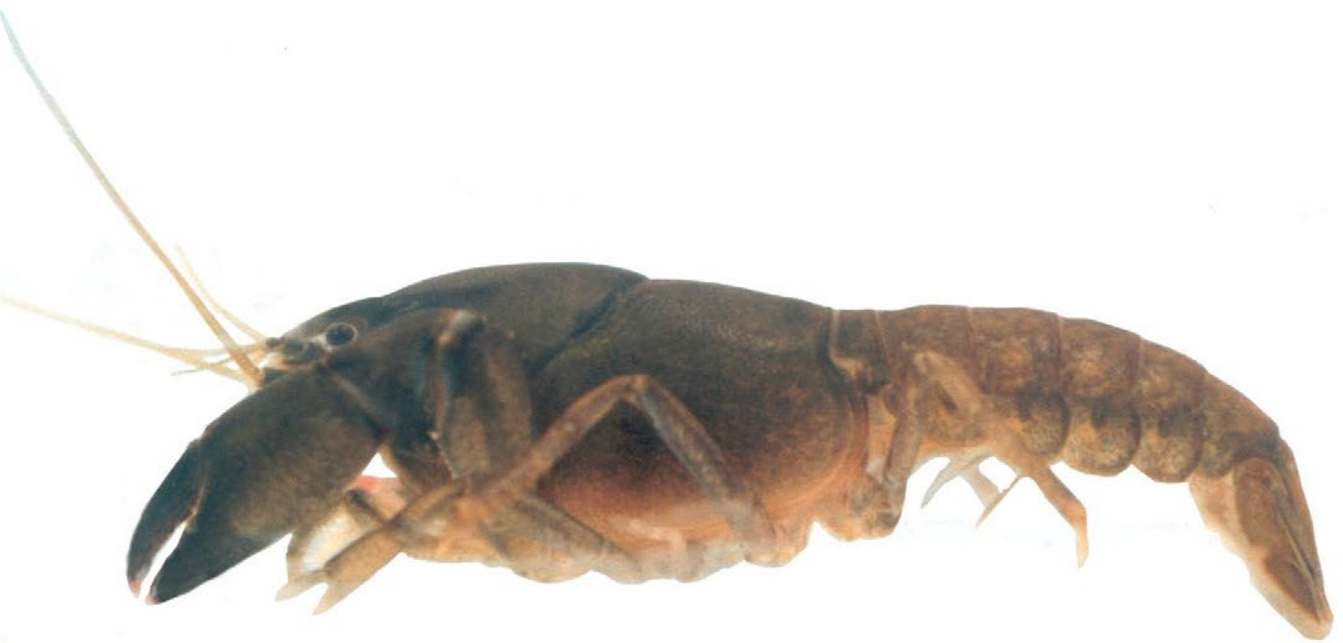

Figure 3. Parastacus buckupi sp. nov, habitat and living specimens. A, B, Typical habitat, a first order stream at Maquiné, state of Rio Grande do Sul; C, living specimen, habitus, dorsal view. Photographs by Fábio S. Vilella. No available information of scale in photograph C. 


\section{Parastacus pilicarpus sp. nov.}

(Figs. 4-8)

Type material. Holotype: male, Brazil, Santa Catarina, Morro Grande, Bacia do Rio Araranguá (2841'57.44”S 4948'8.81”W), 20/VIII/2015, coll. C. Feltrin \& F.H. Llanos (MZUSP 36516). Paratypes: 1 - Brazil, Santa Catarina: one female, same data as holotype (UFRGS 6303); 2A and 2B - two males, same data as holotype (UFRGS 6304); 3 - one female, same data as holotype (UFRGS 6305); 4 - one male, same data as holotype (UFRGS 6306); 5 - one juvenile, same data as holotype (UFRGS 6506).

Etymology. Latin: pili = hair; carpus = an article of the cheliped.

Diagnosis. Wide front with a short triangular rostrum. Rostral apex inverted U-shaped and unarmed. Suborbital angle $>90^{\circ}$. Postorbital carinae weakly proeminet. Cervical groove weekly V-shaped. Areola wide, $2.5 \mathrm{x}$ as long as wide. Mandible with caudal process bicuspidate with one cephalodistal cusp and one small distoproximal cusp. Incisive lobe with nine teeth. The first tooth from the anterior margin is the largest. S2 pleurae low and short with shallow groove parallel to margin. Epistome with the anteromedian lobe heptagonal, as long as wide. Antennal scale lateral margin curved with a very strong terminal spine. Distal portion of the cheliped carpus with tufs of longs e simple setae. Chelipeds laterally flattened with the cutting edge of the fingers densely covered by setae.

Description of the holotype. Rostrum: triangular, wider than long (RL $64.86 \%$ of RW), short ( $8.87 \%$ of $\mathrm{CL}$ ), reaching the proximal portion of the second article of the antennular peduncle (Fig. 4A-C). Dorsum apex inverted "U"-shaped, apex lacking spine (Fig. 4B, C). Few plumose setae on lateral margins. Rostral sides convergent and rostral basis parallel. Carinae almost straight, prominent and large, extending back to carapace, surpassing rostral basis (Fig. 4B, C).

Cephalon: Carapace lacking spines or tubercles. CeL $65.1 \%$ of CL. Eyes large (CMW 81.9\% of OW); suborbital angle $>90^{\circ}$, unarmed (Fig. 4A-C). Front wide (FW $49.2 \%$ of CW). Postorbital carinae longer than rostral carinae (RCL 57.5\% of POCL) and weakly prominent. Lateral cephalic edge with sparse setation (Fig. 4A-C).

Thorax: carapace laterally compressed, deep and narrow (CD $51 \%$ of CL; CW $40 \%$ of CL). Cervical groove weekly V-shaped (Fig. 4A). Branchiocardiac grooves conspicuous (Fig. 4A). Areola wide, $2.5 \mathrm{x}$ as long as wide ( $34.8 \%$ of CL) (Fig. $4 \mathrm{~A})$.

Pleon: lacking spines or tubercles, short and wide (AL 72.3\% of CL; AW 92\% of CW), smooth, sparsely covered with small setae on pleural margins (Fig. 4A). Pleural somites with rounded posterior margins. S1 pleurae with a large distal lobe overlapped by S2 pleurae. S2 pleurae low and short with shallow groove parallel to margin (Fig. 4D).

Tailfan: telson weakly calcified in the distal portion, subrectangular, longer than wide ( $\mathrm{TeW} 81.7 \%$ of TeL), with inconspicuous sharp spines on lateral margins; rounded distal margin with abundant long plumose setae and short simple setae. Dorsal surface with tufts of short setae and inconspicuous dorsomedian longitudinal groove (Fig. 4G). Uropod protopod bilobed, with rounded and unarmed margins; proximal lobe largest; exopod lateral margin bears a small and sharp spine, mid-dorsal carina few prominent, ending in a sharp spine; transverse suture (diaeresis) straight, with three dorsolateral spines (outer) and two dorsolateral spines (inner) on right exopod and two dorsolateral spines (outer) and three dorsolateral spine (inner) on the left exopod; endopod, mid-dorsal carina few prominent, ending in a very sharp spine; lateral margin with one sharp spine at level of diaeresis (Fig. 4G).

Epistome: anterolateral section with a sharp conical projection. Posterolateral section smooth and with deep lateral grooves converging to the basis of the anteromedian lobe, and large median circular concavity. Anteromedian lobe heptagonal, as long as wide, apex acute and straight, reaching the median part of antepenultimate article of antennal peduncle; dorsal surface straight, and basis with a shallow groove (Fig. 5A).

Thoracic sternites: SLP4 smallest and close to each other, median keel present and not inflated; SLP5 small and close to each other, median keel present and not inflated; SLP6 larger than SLP4 and SLP5, separated to each other and with a slightly concave surface, median keel not inflated; SLP7 largest, close to each other and 
A

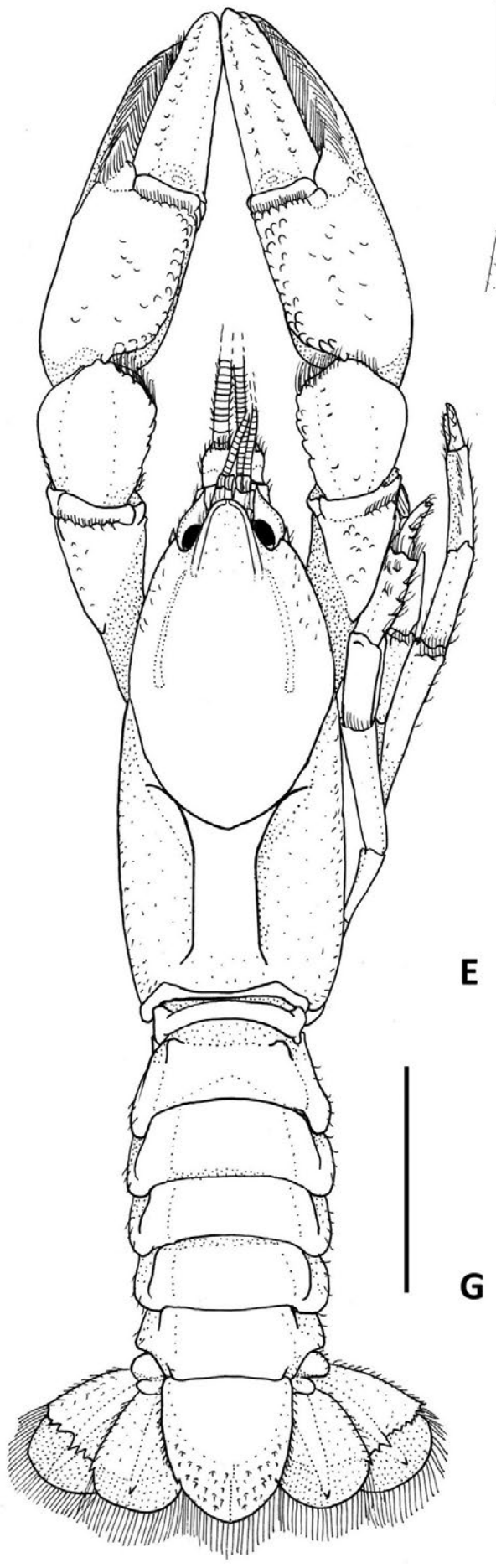

E

G
B

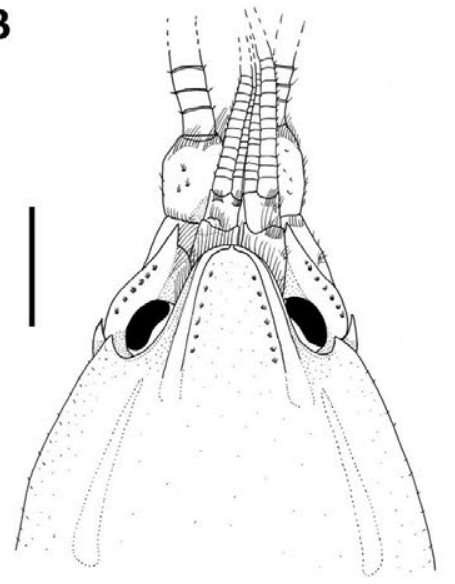

C

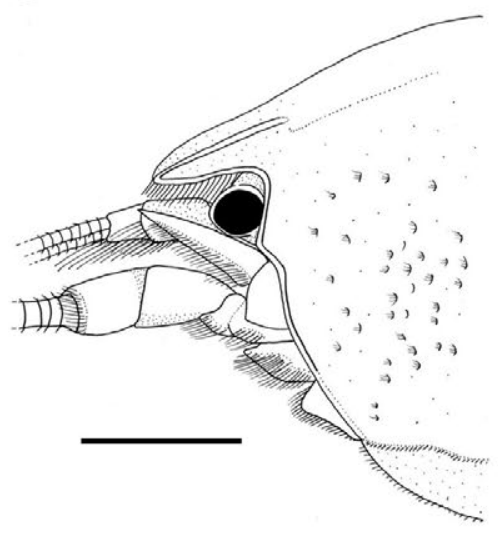

D
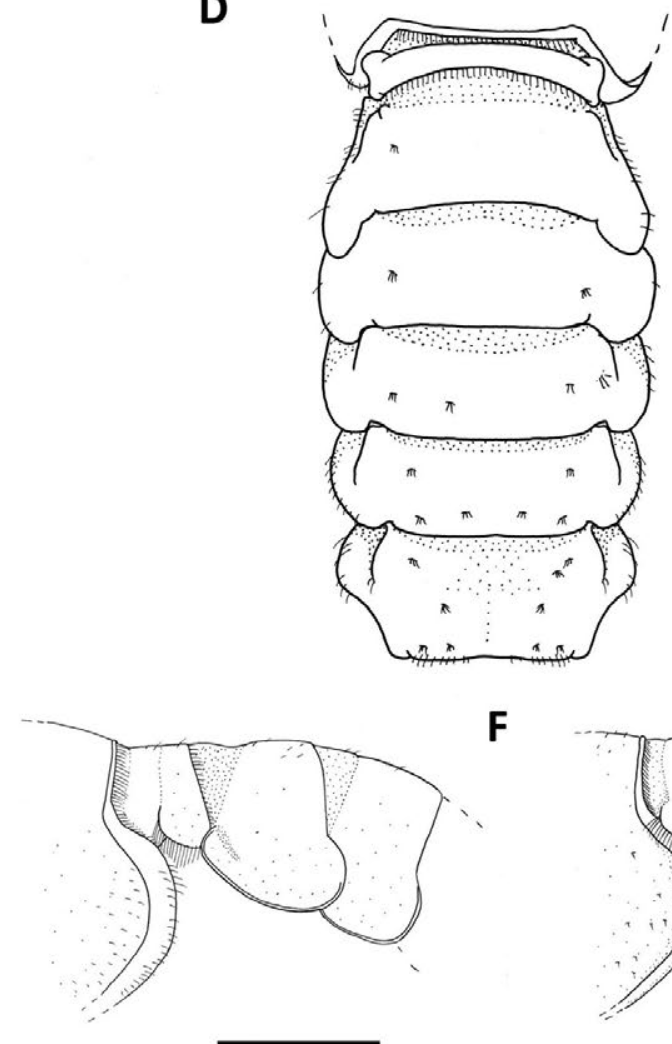

F
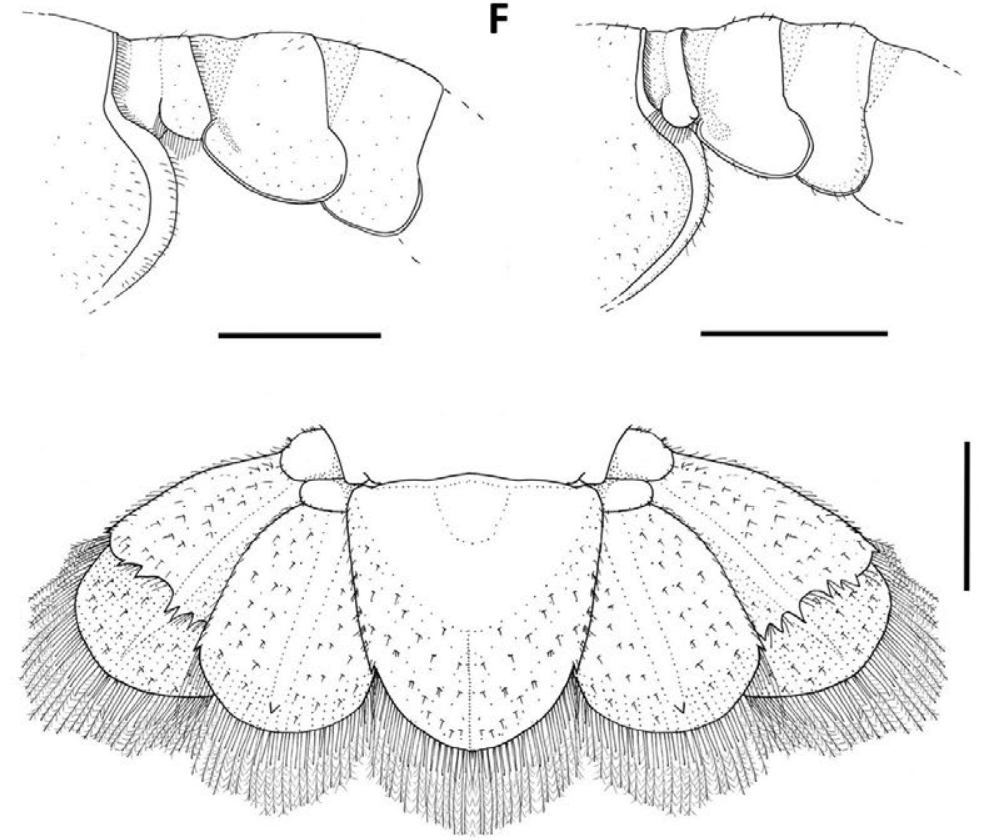

Figure 4. Parastacus pilicarpus sp. nov. A, habitus dorsal view (holotype); B, cephalon dorsal view (holotype); C, cephalon lateral view (holotype); D, female pleon, dorsal view (paratype 1); E, male first to third pleonal pleura (holotype); F, female first to third pleonal pleura (paratype 1); G, telson and uropods dorsal view (holotype). Scale bars: A, D, F-1 cm; E - 5 mm; C, G - $3.33 \mathrm{~mm}$; B $-2.5 \mathrm{~mm}$ 
with surface slightly concave, median keel not inflated, bullar lobes absent; SLP8 larger than SLP4, SLP5 and SLP6 and with a slightly concave, median keel absent, vertical arms of paired sternopleural bridges close to each other, bullar lobes close to each other and clearly visible (Fig. 5B, C).

Antennule: internal ventral border of basal article with small sharp spine (Fig. 5A).

Antenna: when extended back reaching up to the posterior margin of the carapace; antennal scale widest distal at midlength, almost reaching the end of third antennal article, ASW 59\% of ASL (Fig. 5A, D), lateral margin curved with a very strong terminal spine and distal margin emarginated. Coxa with prominent carina and blunt spine above nephropore. Basis unarmed (Fig. 5A).

Mandible: cephalic molar process molariform, caudal molar process bicuspidate with one cephalodistal cusp and one small distoproximal cusp. Incisive lobe with nine teeth. The first tooth from the anterior margin is the largest (Fig. 5E).

Third maxilliped: ischium, ventral surface covered by tufts of long and simples setae (Fig. 5F), dorsal surface glabrous (Fig. 5G), crista dentata bearing 23 and 24 teeth in right and left ischium respectively. Merus ventral surface follows the same pattern that of ischium. Exopod longer than ischium, with flagellum reaching proximal margin of merus (Fig. 5F, G).

First pair of pereiopods (chelipeds): laterally flattened and subequal (RPrT 30.1\% of RPrL; LPrT $31.8 \%$ of LPrL) (Fig. 5A, H, I). Ischium ventral surface with 13 tubercles. Merus: right merus (RML) 50.2\% of propodus length (RPrL); left merus (LML) 54.2\% of propodus length ( $\mathrm{LPrL})$; ventral surface with two longitudinal series of tubercles: inner series with 13 tubercles, outer 13 and mesial 12, arranged irregularly on right merus; inner series bearing 13 tubercles, outer 13 and mesial 13, arranged irregularly on left merus; dorsal and midventral spines absent. Carpus with dorsomedial surface divided longitudinally by shallow groove and the distal margin covered with tuffs of long and simple setae (Fig. 5A, H, I); internal dorsolateral margin without tubercles; inner surface without tubercles; carpal spine absent (Fig. 5I). Propodus width (RPrW and LPrW) $47.7 \%$ of length in right cheliped and $49.8 \%$ in left cheliped; dorsal surface of palm with squamose tubercles irregularly distributed (Fig. 5H, I); inner margin without tubercles; ventral surface bearing two rows of squamose tubercles, reaching the beginning of the fixed finger (Fig. 5H). Dactylus: moving subvertically, right dactylus (RDL) $51.9 \%$ of propodus length (RPrL), left dactylus (LDL) $58.2 \%$ of left propodus (LPrL); dorsal surface without tubercles (Fig. 5I). Cutting edge of fingers densely covered by tufts of long and simple setae. Fixed finger and dactylus bearing eight teeth, being the fourth teeth the largest. (Fig. 5H, I).

Second pair of pereiopods: ventral and dorsal surface of carpus, propodus and dactylus with sparse covering of simple and long setae (Fig. 5J).

Gonopores: Presence of both genital apertures on coxae of third and fifth pairs of pereiopods. Female gonopores semi-ellipsoidal (maximum diameter 1.69 $\mathrm{mm}$ ) with a well-calcified membrane. Male gonopores rounded, opening onto apical end of a small, fixed, calcified and truncated phallic papilla, close to inner border of ventral surface of coxae of fifth pair of pereiopods. Male cuticle partition present (Fig. 5B).

Branchial count: $20+\mathrm{epr}+\mathrm{r}$. Branchial arrangement follows the same described by Huxley (1879) and Hobbs (1991) with the epipod of the first maxilliped with rudimentary podobranchial filaments.

Measurements. Holotype male, CL $21.63 \mathrm{~mm}$ and TL $44.78 \mathrm{~mm}$. In type series, CL ranging from 12.90 to $33.54 \mathrm{~mm}$ (22.65 $\pm 7.76 \mathrm{~mm})$. FW/CW: $0.46 \pm 0.06$ (min: 0.35; max: 0.56). RL/RW: $1.22 \pm 0.1$ (min: 0.76; $\max : 1.54)$. MCW/OW: $0.82 \pm 0.1$ (min: 0.69; $\max$ : 0.96). Postorbital carina longer than rostral carina in all specimens analyzed. CW/PW: $1.10 \pm 0.07$ (min: 01.08; max: 1.25). AreW/RW: $1.15 \pm 0.25$ (min: 1.00; max: 1.65) (Tab. 2).

Color of living specimens. Rostrum dark brown. Antennal flagellum light brown. Cephalothorax anterior and lateral regions dark reddish brown to light reddish brown. First pair of pereiopods dark reddish brown dorsally and reddish brown in ventral and lateral surfaces. Dactylus dark reddish brown in the proximal portion and reddish brown distally. Pereiopod pairs 2-5 light reddish brown to reddish brown. Dorsal pleon and tailfan reddish brown (Fig. 6C). 


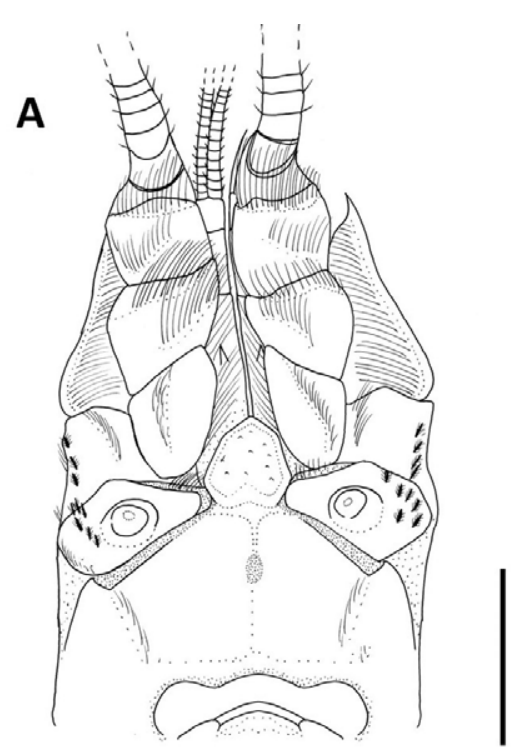

E

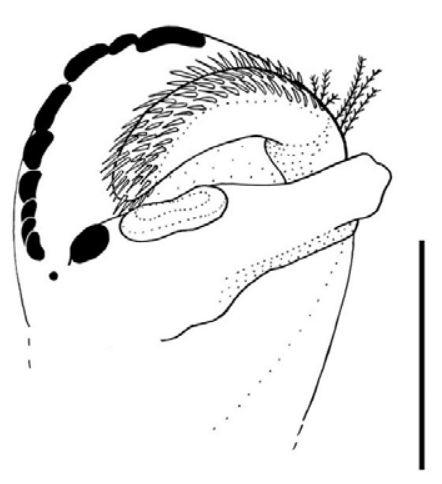

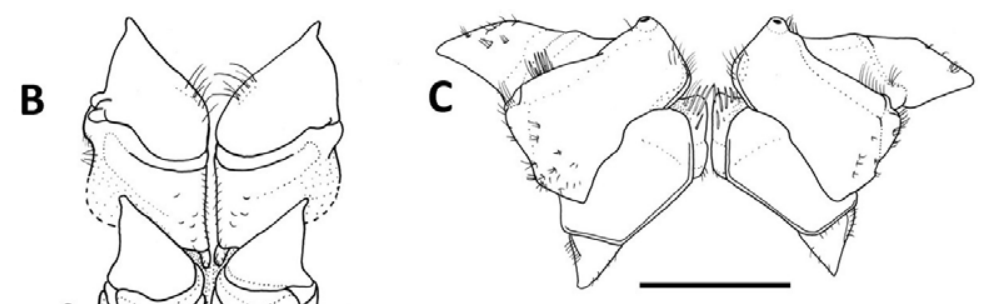
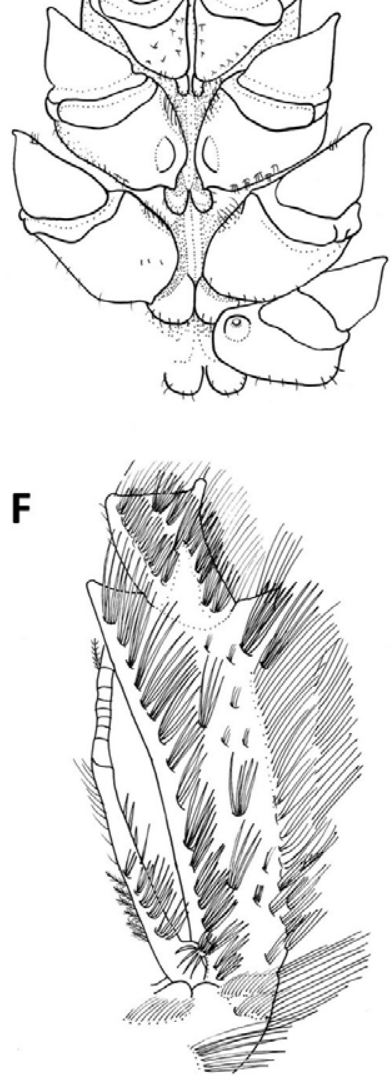

G

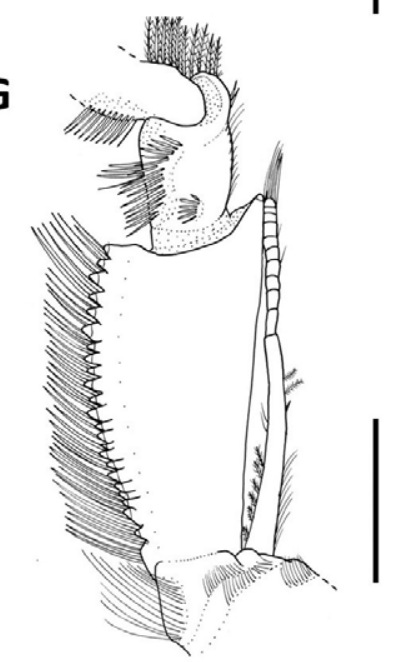

J

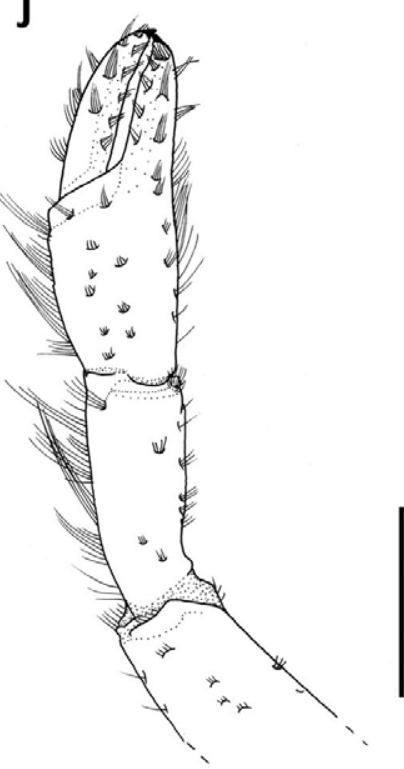

Figure 5. Parastacus pilicarpus sp. nov. A, epistome (holotype); B, thoracic sternites and gonopores (holotype); C, thoracomere 8, caudal view (holotype); D, antennal scale lateral view (paratype 1); E, mandible (paratype 1); F, third maxilliped ventral view (paratype 1); G, third maxilliped dorsal view (paratype 1); H, first pereiopod lateral view (holotype); I, first pereipod dorsal view (holotype); J, second pereiopod lateral view (holotype). Scale bars: A, E-2.50 mm; B, C, H, J-5 mm; D - $2.00 \mathrm{~mm}$; F, G, I- $3.33 \mathrm{~mm}$. 
Remarks. Parastacus pilicarpus sp. nov. is morphologically similar to P. buckupi sp. nov. in having the rostral apex inverted U-shaped and short rostral carinae. Parastacus pilicarpus sp. nov. is also similar to $P$. buckupi sp. nov., P. fluviatilis and P. pilimanus by the presence of tufts of long and simple setae on the cutting edge of fingers of chelipeds (Fig. 7). Parastacus pilicarpus sp. nov. differs from all other Parastacus spp. in having the epistome anteromedian lobe heptagonal, as long as wide (Fig 5A), antennal scale lateral margin curved with a very strong terminal spine (Fig. 5D), mandible incisive lobe with the first tooth from the anterior margin being the largest and the presence of tufts of long and simple setae in the distal portion of carpus (Fig. 5I). All specimens are intersexed. In males paratypes the female gonopores are semi-ellipsoidal (average maximum diameter $1.69 \mathrm{~mm}$ ) covered by a calcified membrane (Fig. 5B). The male gonopores are similar in all type material.

Habitat and Ecology. All animals were collected in the headwaters of Manoel Alves stream which is considered a first order stream. Based on photographs (Fig. 6A, B), it is possible to infer that the margins are surrounded by riparian vegetation, gravel and rocks probably from basaltic origin. Despite the absence of information on burrowing behavior and burrow morphology, the possibility of the species shows some burrowing ability, cannot be discarded since according to Buckup and Rossi (1980) burrowing behavior is probably found in all species of Parastacus.

Table 2. Measurements ( $\mathrm{mm}$ ) of the type series of Parastacus pilicarpus sp. nov. (* broken appendage). For abbreviations see Material and Methods section.

\begin{tabular}{|c|c|c|c|c|c|c|c|}
\hline & $\begin{array}{c}\text { Holotype } \\
\text { (MZUSP 36516) }\end{array}$ & $\begin{array}{c}\text { Paratype 1 } \\
\text { (UFRGS 6303) }\end{array}$ & $\begin{array}{c}\text { Paratype 2A } \\
\text { (UFRGS 6304) }\end{array}$ & $\begin{array}{c}\text { Paratype 2B } \\
\text { (UFRGS 6304) }\end{array}$ & $\begin{array}{c}\text { Paratype } 3 \\
\text { (UFRGS 6305) }\end{array}$ & $\begin{array}{c}\text { Paratype } 4 \\
\text { (UFRGS 6306) }\end{array}$ & $\begin{array}{c}\text { Paratype } 5 \\
\text { (UFRGS 6506) }\end{array}$ \\
\hline Sex & $\mathrm{M}$ & F & $\mathrm{M}$ & $\mathrm{M}$ & $\mathrm{F}$ & $\mathrm{M}$ & Juv \\
\hline $\mathrm{TL}$ & 44.78 & 64.62 & 38.57 & 43.53 & 65.17 & 32.61 & 25.62 \\
\hline CL & 21.63 & 33.54 & 18.87 & 21.87 & 32.70 & 17.10 & 12.90 \\
\hline CW & 8.66 & 13.97 & 7.40 & 9.17 & 12.95 & 6.18 & 4.80 \\
\hline $\mathrm{CD}$ & 11.04 & 17.05 & 9.55 & 10.98 & 16.37 & 8.53 & 6.38 \\
\hline CSL & 14.08 & 22.37 & 12.36 & 14.17 & 22.16 & 11.03 & 8.76 \\
\hline $\mathrm{RL}$ & 1.92 & 3.35 & 1.87 & 2.19 & 3.65 & 1.69 & 1.99 \\
\hline RW & 2.96 & 4.34 & 2.22 & 2.37 & 3.80 & 2.06 & 1.52 \\
\hline CMW & 1.13 & 1.60 & 0.96 & 1.25 & 1.62 & 0.96 & 0.77 \\
\hline OW & 1.38 & 2.16 & 1.39 & 1.34 & 1.96 & 1.00 & 1.02 \\
\hline FW & 4.26 & 4.93 & 3.64 & 4.20 & 6.01 & 3.37 & 2.71 \\
\hline RCL & 2.80 & 4.20 & 2.80 & 3.49 & 4.17 & 2.84 & 2.17 \\
\hline POCL & 4.87 & 5.68 & 4.14 & 3.39 & 8.09 & 4.58 & 4.45 \\
\hline ASL & 2.61 & 4.12 & 2.37 & 2.86 & 4.81 & 2.09 & 2.06 \\
\hline ASW & 1.54 & 1.90 & 1.12 & 1.26 & 1.92 & 1.09 & 0.81 \\
\hline $\mathrm{AuL}$ & 7.54 & 9.00 & 6.21 & 7.72 & 10.81 & 6.37 & 3.91 \\
\hline $\mathrm{AuW}$ & 3.01 & 4.96 & 2.23 & 3.93 & 4.15 & 2.06 & 1.62 \\
\hline PW & 7.97 & 11.15 & 17.91 & 8.19 & 12.14 & 5.92 & 4.45 \\
\hline PL & 15.63 & 25.24 & 13.79 & 16.18 & 31.62 & 12.29 & 9.59 \\
\hline RPrT & 5.40 & * & 3.76 & 3.78 & * & 3.44 & 1.35 \\
\hline RPrL & 17.95 & * & 12.73 & 14.32 & * & 12.53 & 6.73 \\
\hline RPrW & 8.57 & * & 6.21 & 6.59 & * & 5.73 & 2.51 \\
\hline RML & 9.02 & * & 7.96 & 8.34 & * & 7.34 & 470 \\
\hline $\mathrm{RDL}$ & 9.32 & * & 7.51 & 8.50 & * & 6.78 & 3.92 \\
\hline LPrT & 5.35 & 9.43 & 3.69 & 5.99 & * & 3.58 & 1.87 \\
\hline LPrL & 16.81 & 33.12 & 13.02 & 17.03 & * & 12.93 & 7.63 \\
\hline LPrW & 8.38 & 13.89 & 6.24 & 8.76 & * & 6.31 & 3.12 \\
\hline LML & 9.11 & 16.60 & 8.13 & 9.32 & * & 7.20 & 5.24 \\
\hline LDL & 9.79 & 18.62 & 7.26 & 8.37 & * & 7.12 & 4.75 \\
\hline $\mathrm{TeL}$ & 6.40 & 9.21 & 5.56 & 6.29 & 9.75 & 4.68 & 3.86 \\
\hline $\mathrm{TeW}$ & 5.23 & 8.04 & 4.64 & 5.52 & 8.02 & 4.08 & 3.00 \\
\hline Gon & 1.22 & 1.69 & 0.92 & 1.3 & 1.64 & 0.78 & 0.47 \\
\hline
\end{tabular}



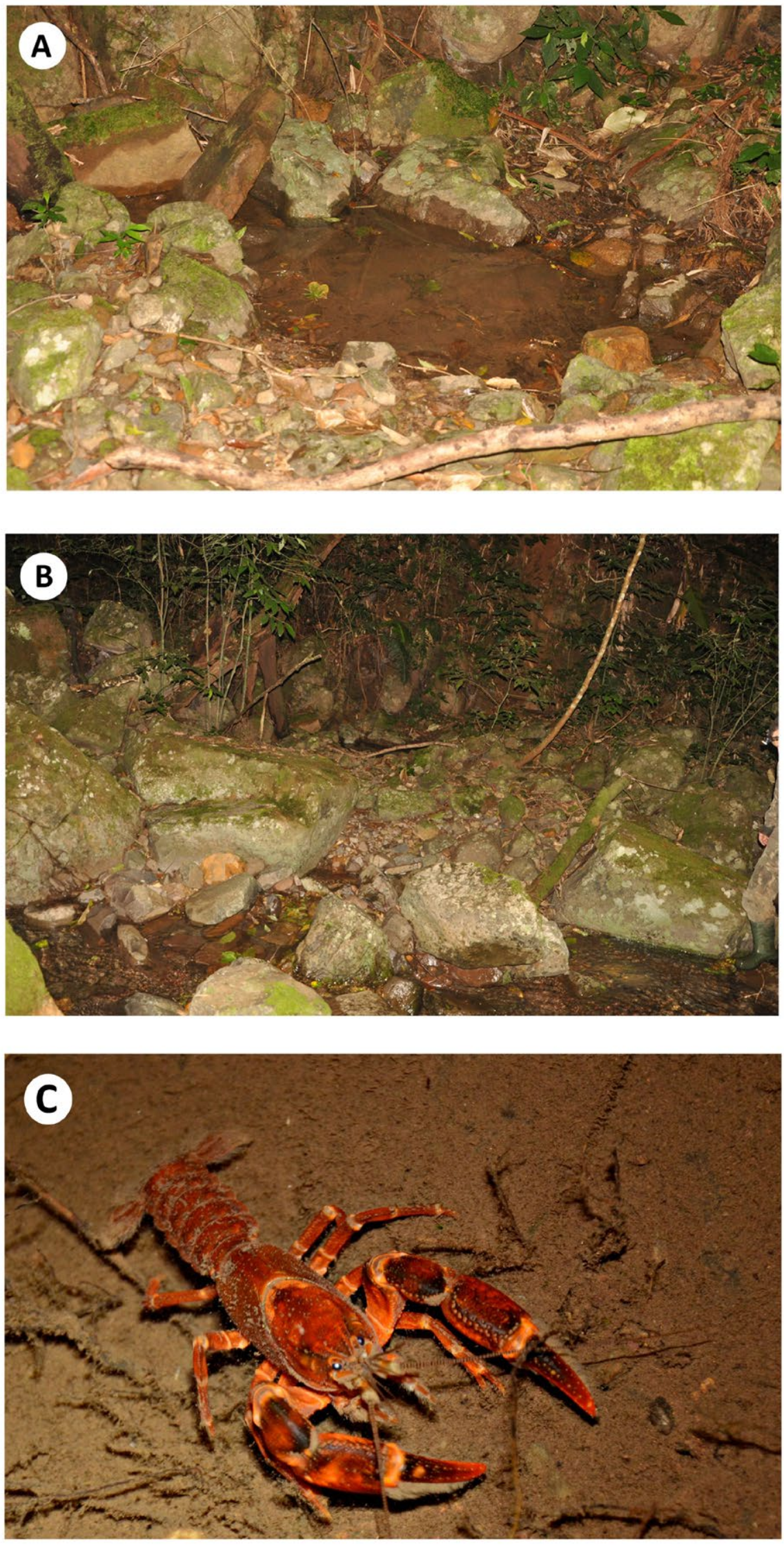

Figure 6. Parastacus pilicarpus sp. nov., habitat and living specimens. A, B, Typical habitat, a first order stream in the municipality of Morro Grande, state of Santa Catarina; C, living specimen. Photographs by Caio R. M. Feltrin. No available information of scale in photograph C. 


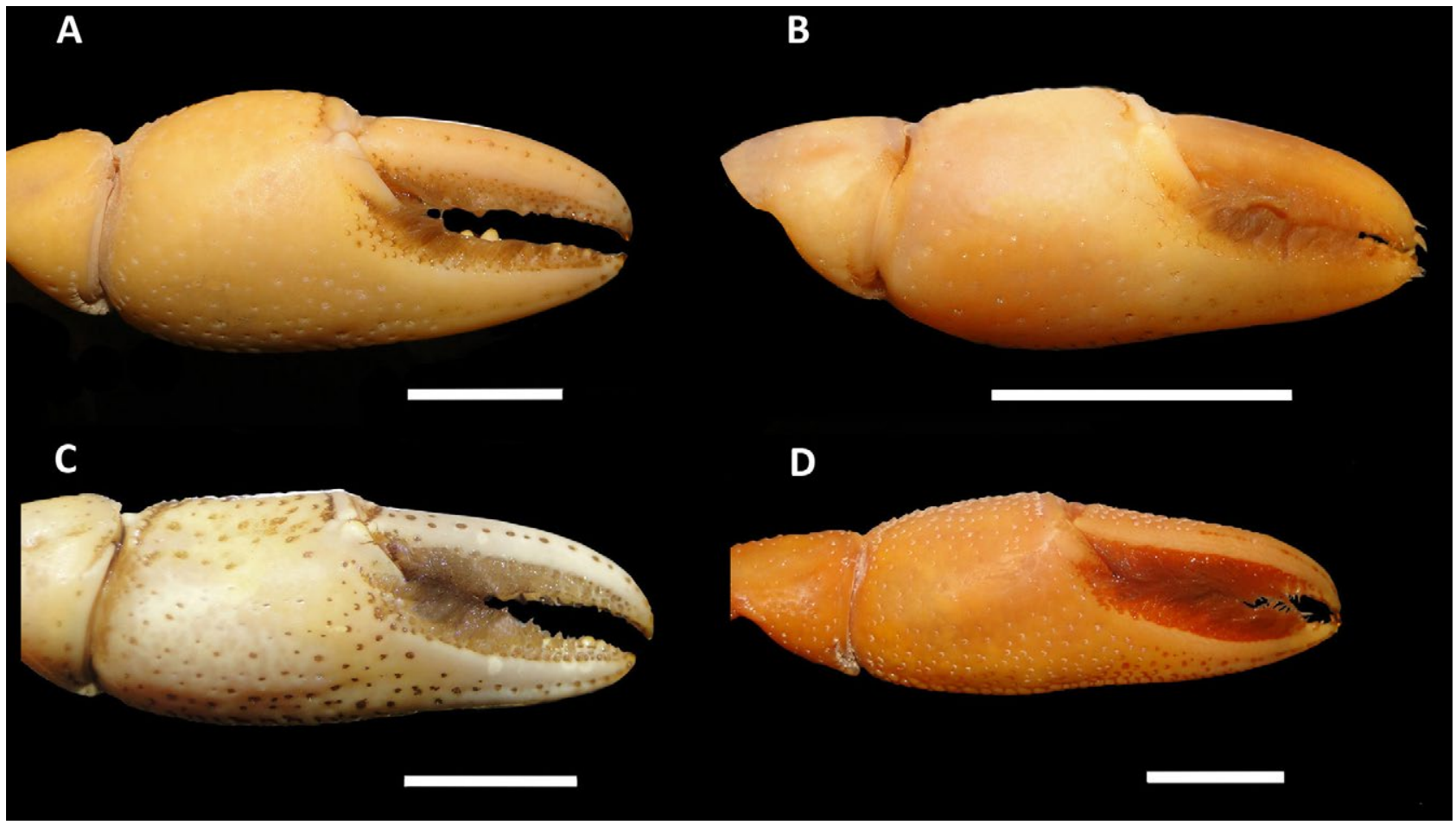

Figure 7. Comparative board of the chelipeds of selected species of genus Parastacus Huxley, 1879 with pilous cutting edge of fingers. A - P. buckupi sp. nov. (holotype); B - P. pilicarpus sp. nov. (holotype); C - P. fluviatilis Ribeiro \& Buckup in Ribeiro et al. (2016) (UFRGS 2704); D - P. pilimanus (von Martens, 1869) (UFRGS 2413, CL 38.74). Scale bars: $1 \mathrm{~cm}$.
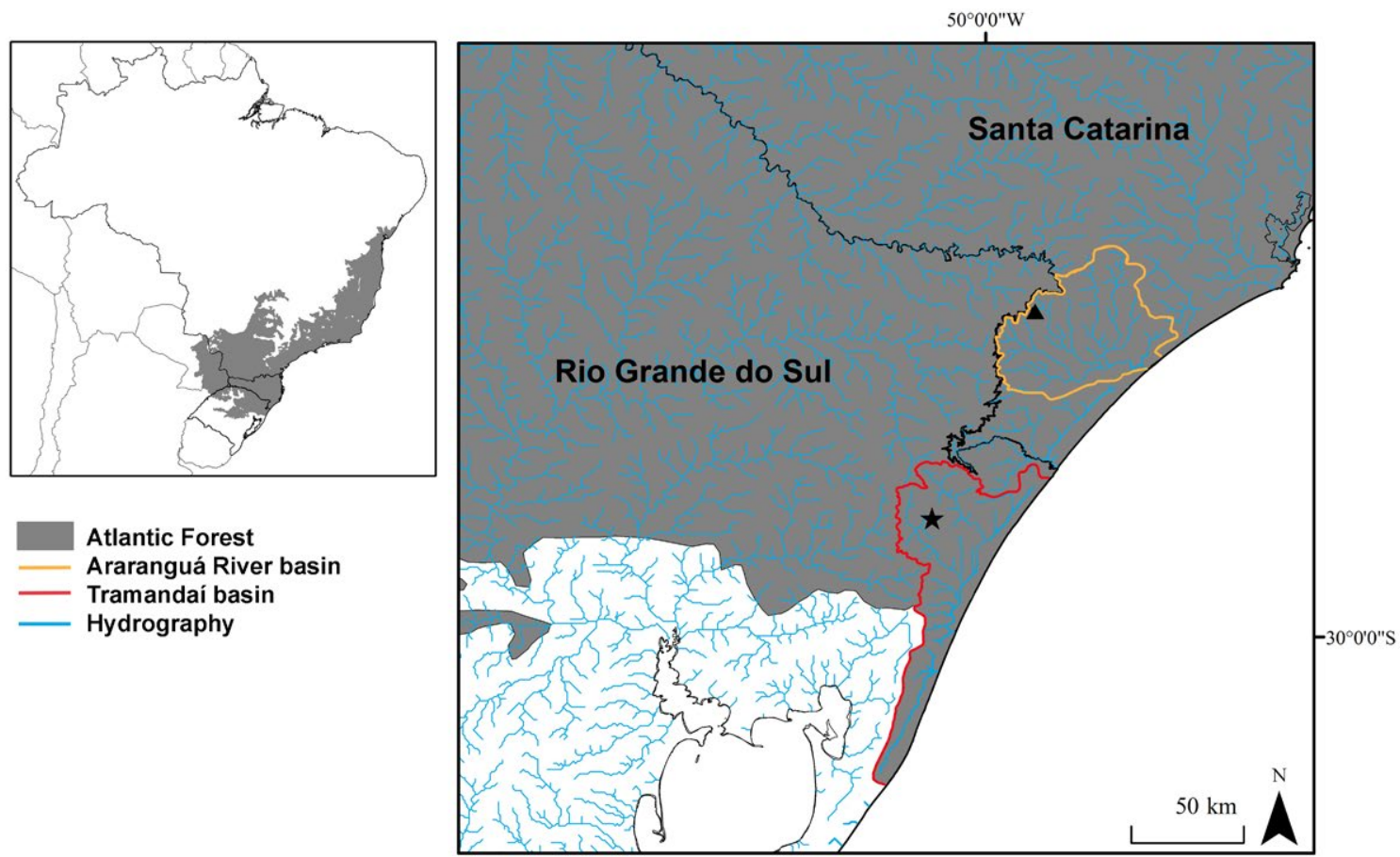

Figure 8. Distribution of Parastacus buckupi sp. nov. (star) and P. pilicarpus sp. nov. (triangle) in the states of Rio Grande do Sul and Santa Catarina, southern Brazil. 
Distribution. Parastacus pilicarpus sp. nov. is so far recorded in the headwater of Manoel Alves stream in the municipality of Morro Grande, state of Santa Catarina, southern Brazil (Fig. 8).

Conservation status. The EOO was estimated at approximately $1,037.123 \mathrm{~km}^{2}$ (Fig. 8), indicating that this species should be included in the Endangered - EN category, in which the EOO is less than $5,000 \mathrm{~km}^{2}$ (IUCN, 2012). This classification as EN takes into consideration the subitem "a": for an EOO, which is severely fragmented; and subitem "b" (iii): continuing decline in quality of habitat. The region of Araranguá River basin is target of industrial and agricultural waste (Araújo et. al., 1989). The Araranguá River basin is recognized as an endemic area of fish species (Malabarba and Isaia, 1992; Reis and Schaefer, 1998), as Hollandichthys taramandahy Bertaco \& Malabarba, 2013 (Lambaristriped). Unfortunately, the area shows high level of anthropogenic disturbances, as the deforestation of riparian forest (Bertaco and Malabarba, 2013). However, we do not have enough surveys to make that claim yet for the state of Santa Catarina. Consequently, the EOO for P. pilicarpus sp. nov. could be underestimated in our study. Taking this into account, we decided to classify this species as DATA DEFICIENT.

\section{ACKNOWLEDGeMENTS}

This study was completed by A.F. Huber in the course of obtaining a Bachelor's degree in Biological Sciences from the Federal University of Rio Grande do Sul. The authors would like to thank Conselho Nacional de Desenvolvimento Científico e Tecnológico (CNPq) for the scholarship granted to A.F. Huber and for the fellowship granted to P.B. Araujo (PQ 305900/2014-5), Coordenação de Aperfeiçoamento de Pessoal de Nível Superior (CAPES) that provided a Doctorate Scholarship to F.B. Ribeiro. We also would like to thank Dra. Kelly Martinez Gomes for the help in conservation analysis, Dr. Fábio Silveira Vilella for the photographs of P. buckupi sp. nov. and Caio Roberto Magagnin Feltrin for collecting the specimens and the photographs of $P$. pilicarpus sp. nov.

\section{References}

ANA - Agência Nacional de Águas (Brasil). 2006. Topologia hídrica: método de construção e modelagem da base hidrográfica para suporte à gestão de recursos hídricos: versão 1.11. Brasília, Agência Nacional de Águas, Superintendência de Gestão da Informação, 29p.

Araújo, N.B.; Mosimann, R.M.S. and Fernandes, L.F. 1989. Contribution to knowledgement of the diatoms from the mouth of the Araranguá river. Ínsula, Florianópolis, 19: 305-334.

Becker, F.G.; Irgang, G.V.; Hasenack, H.; Vilella, F.S. and Verani, N.F. 2004. Land cover and conservation state of a region in the southern limit of the Atlantic Forest (river Maquiné basin, Rio Grande do Sul, Brazil). Brazilian Journal of Biology, 64: 569-582.

Bencke, G.A. and Kindel, A. 1999. Bird counts along an altitudinal gradient of Atlantic forest in northeastern Rio Grande do Sul, Brazil. Ararajuba, 7: 91-107.

Bertaco, V.A. and Malabarba, L.R. 2013. A new species of the characid genus Hollandichthys Eigenmann from coastal rivers of southern Brazil (Teleostei: Characiformes) with a discussion on the diagnosis of the genus. Neotropical Ichthyology, 11: 767-778.

Buckup, L. 2003. Família Parastacidae. p. 117-141. In: G.A.S. Melo (Org), Manual de identificação dos Crustacea Decapoda de água doce do Brasil. São Paulo, Ed. Loyola.

Buckup, L. and Rossi, A. 1980. O Gênero Parastacus no Brasil (Crustacea, Decapoda, Parastacidade). Revista brasileira de Biologia, 40: 663-681.

Buckup, L. and Rossi, A. 1993. Os Parastacidae do espaço meridional andino (Crustacea, Astacidea). Revista brasileira de Biologia, 53: 167-176.

Crandall, K.A. and De Grave, S. 2017. An updated classification on the freshwater crayfishes (Decapoda: Astacidae) of the world, with a complete species list. Journal of Crustacean Biology, 37: 615-653.

ESRI. 2009. ArcGIS Desktop: Release 9.3. Environmental Systems, Research Institute Redlands, CA.

Faxon, W. 1898 Observations on the Astacidae in the United States National Museum and in the Museum of Comparative Zoology, with descriptions of new species. Proceedings of the United States National Museum, 20: 642-694.

Hobbs, H.H. Jr. 1987. A review of the crayfish genus Astacoides (Decapoda: Parastacidae). Smithsonian Contributions to Zoology, 443: 1-50.

Hobbs, H.H. Jr. 1991. A new generic assignment for a South American crayfish (Decapoda, Parastacidae) with revised diagnoses of the South American genera and comments on the parastacid mandible. Proceedings of the Biological Society of Washington, 104: 800-811. 
Holdich, D.M. 2002. Biology of Freshwater Crayfish. Oxford, Blackwell Science, 702p.

Huxley, T.H. 1879. On the classification and the distribution of the crayfishes. Proceedings of the Zoological Society of London, 1878: 752-788.

IBGE - Instituto Brasileiro de Geografia e Estatística. 1990. Rio de Janeiro, Geografia do Brasil; Região Sul, 419p.

IUCN - International Union for Conservation of Nature. 2012. IUCN Red List Categories and Criteria: Version 3.1, Second edition. IUCN, Gland, Switzerland and Cambridge, 32p.

Malabarba, L.R. and Isaia, E.A., 1992. The fresh water fish fauna of the rio Tramandaí drainage, Rio Grande do Sul, Brazil, with a discussion of its historical origin. Comunicações do Museu de Ciências e Tecnologia, Pontifícia Universidade Católica do Rio Grande do Sul, Série Zoologia, 5: 197-223.

Martens, E. von. 1869. Südbrasilianische Süss-und BrackwasserCrustaceen nach den Sammlungen des Dr. Reinh. Hensel. Archiv für Naturgeschichte, 35: 1-37.

Melo, G.A.S. 2003. Manual de identificação dos Crustacea Decapoda de água doce do Brasil. São Paulo, Ed. Loyola, 430p.

Mittermeier, R.A.; Gil, P.R.; Hoffmann, M.; Pilgrim, J.; Brooks, T.; Mittermeier, C.G.; Lamoreux, J. and Fonseca, G.A.B. 2004. Hotspots Revisited: Earth's Biologically Richest and Most Endangered Terrestrial Ecoregions. CEMEX/Agrupación Sierra Madre, 432p.

Morgan, G.J. 1997. Freshwater crayfish of the genus Euastacus Clark (Decapoda: Parastacidae) from New South Wales, with a key to all species of the genus. Records of the Australian Museum, Supplement, 23: 1-110.

Morrone, J.J. 2014. Biogeographical regionalisation of the Neotropical region. Zootaxa, 3782: 1-110.

Philippi, R.A. 1882 Zoología chilena. Sobre los Astacus. Anales de la Universidad de Chile, 61: 624-628.

Poeppig, E. 1835. Reise in Chile, Peru und auf dem Amazonas strome, während der Jahre 1827-1832, Vol. 1. Leipzig, Fleischer und Hinrichs, 18, 466p.

Reis, R.E. and Schaefer, S.A., 1998. New cascudinhos from Southern Brazil: systematics, endemism, and relationships (Siluriformes, Loricariidae, Hypoptopomatinae). American Museum Novitates, 3254: 1-25.
Ribeiro, F.B. and Araujo, P.B. 2017. Designation of a neotype for Parastacus nicoleti (Philippi, 1882) (Crustacea: Decapoda: Parastacidae). Zootaxa, 4338: 393-400.

Ribeiro, F.B.; Buckup, L.; Gomes, K.M. and Araujo, P.B. 2016. Two new species of South American freshwater crayfish genus Parastacus Huxley, 1879 (Crustacea: Decapoda: Parastacidae). Zootaxa, 4158: 301-324.

Ribeiro, F.B.; Huber, A.F.; Schubart, D. and Araujo, P.B. 2017. A new species of Parastacus Huxleys, 1879 (Crustacea, Decapoda, Parastacidae) from a swap forest in southern Brazil. Nauplius, 25: e2017008.

Ribeiro, M.C.; Metzger, J.P.; Martensen, A.C.; Ponzoni, F.J. and Hirota, M.M. 2009. The Brazilian Atlantic Forest: How much is left, and how is the remaining forest distributed? Implications for conservation. Biological Conservation, 142: 1141-1153.

Riek, E.F. 1971. The freshwater crayfishes of South America. Proceedings of the Biological Society of Washington, 84: 129-136.

Rudolph, E.H. 1997. Aspectos fisicoquímicos del hábitat y morfologia de lãs galerias del camáron excavador Parastacus nicoleti (Philippi, 1882) (Decapoda, Parastacidae) en el sur de Chile. Gayana Zoología, 61: 97-108.

Rudolph, E.H. 2010. Sobre la distribución geográfica de las especies chilenas de Parastacidae (Crustacea: Decapoda: Astacidea). Boletín de Biodiversidad de Chile, 3: 32-46.

Schram, F.R. 2013. Comments on crustacean biodiversity and disparity of body plants. p. 1-33. In: L. Watling and M. Thiel (eds), The natural history of the Crustacea: Funcional morphology \& diversity. Oxford, New York, Oxford University Press.

Sydow, V.G.; Vilella, F.S.; Hartz, S.M. and Rodrigues, G.G. 2008. Ichthyocladius (Diptera, Chironomidae) on loricariid fishes in Atlantic Forest streams: influence of host size and corporal region on larval attachment. Acta Limnologica Brasiliensia, 20: 333-337.

Vilella, F.S.; Becker, F.G.; Hartz, S.M. and Barbieri,G. 2004. Relation between environmental variables and aquatic megafauna in a first order stream of the Atlantic Forest, southern Brazil. Hydrobiologia, 528: 17-30. 